\title{
Mobilisation of iron and manganese from sediments of a Scottish Upland reservoir
}

\author{
Corinna ABESSER* and Ruth ROBINSON
}

School of Geography and Geosciences, University of St Andrew, St Andrews, KY16 9AL, UK

*e-mail corresponding author: c.abesser@bgs.ac.uk

\begin{abstract}
High concentrations of manganese (>50 $\left.\mu \mathrm{g} \mathrm{L}^{-1}\right)$ and iron (>226-467 $\left.\mu \mathrm{g} L^{-1}\right)$ have caused water quality problems at the Megget Reservoir during an excessive draw down of the reservoir water level in 1997/98. Sediment column studies were carried out to investigate how internal processes, namely sediment resuspension and diffusion from the sediment, contribute to the mobilisation of these elements in the water column. It was found that sediment resuspension is by far the more effective mechanism in mobilising iron and manganese and also causes persistent discolouration of the water. Concentrations of up to $80 \mathrm{mg} \mathrm{L}^{-1}$ iron and $16 \mathrm{mg} L^{-1}$ manganese were observed in the experimental core water columns which are equivalent to $490 \mu \mathrm{g} L^{-1}$ and $97 \mu \mathrm{g} L^{-1}$ in a $27 \mathrm{~m}$ water column (= maximum water depth during reservoir draw down in 1997/98). From sediment particle size data it was calculated that wind speeds over $13 \mathrm{~m} \mathrm{~s}^{-1}$ can trigger sediment resuspension at water depths of up to $20 \mathrm{~m}$ and have the potential to disturb sediments in large parts (>25\% at full capacity) of the reservoir. Under current climatic conditions, such wind events are infrequent but increasing wind speeds and rainfall intensities, as predicted by climate change scenarios, may cause resuspension events to become more frequent, reducing the reservoir's water quality over prolonged periods and limiting its use as a drinking water resource. Such resuspension events are also expected to occur in other water bodies in the study region, adversely affecting their water quality and increasing the ecosystem productivity. Diffusion from the sediment mostly affects the cycling of manganese. Maximum concentrations in the experimental columns were equivalent to $70-130 \mu \mathrm{g} L^{-1}$ in a 3-5 $m$ water column and were comparable to in-situ concentrations measured in the bottom waters of the reservoir (3-5 $\mathrm{m}$ above the sediment) during summer stratification. Sediment release is unlikely to cause serious water quality problems as only a limited amount of available manganese is found within the sediment. However, the accumulation of manganese and iron in the bottom waters may increase with changing climatic condition, in particular when the external inputs of these elements increase as a result of higher catchment loading associated with the predicted rise in rainstorm intensities.
\end{abstract}

Key words: iron, manganese, sediment resuspension, diffusion, drinking-water quality, reservoir, laboratory study

\section{INTRODUCTION}

Manganese (Mn) and iron (Fe) are present in water supplies as a result of natural processes involving both catchment erosion and redox-related dissolution of $\mathrm{Fe}$ and Mn-containing minerals at or near the sedimentwater interface. Increased concentrations of these elements in water supply bodies concerns many water authorities in the UK (Heal 2001) and has also caused problems in Australia (Zaw \& Chiswell 1999), the Ukraine (Linnik \& Zubenko 2000) and the USA (Hsiung \& Tisue 1994) where approximately $40 \%$ of the public water supply systems are affected (AWWA 1987). Temporary deterioration in water quality due to increased Mn has occurred in raw waters from the Ellan valley in Wales (Schofield et al. 1991) and in Loch Bradan, south-west Scotland (Little \& Mcfadzean 1991). Increased Mn concentrations were also found in the Megget Reservoir during a forced draw down of the reservoir water level in 1997/98 from 55 m (full capacity) to $27 \mathrm{~m}$ ( $28 \%$ capacity) in order to conduct repairs to the dam. As a result, concentrations at the water treatment works increased to $50 \mu \mathrm{g} \mathrm{L}^{-1}$ for $\mathrm{Mn}$ and to $350 \mu \mathrm{g} \mathrm{L}^{-1}$ for $\mathrm{Fe}$, approaching and exceeding the maximum admissible concentrations in UK drinking water of $50 \mu \mathrm{g} \mathrm{L}{ }^{-1}$ and $200 \mu \mathrm{g} \mathrm{L}{ }^{-1}$, respectively (DWI 2000). Problems with high Mn concentrations in the drinking water have forced the introduction of filtration systems and $\mathrm{Mn}$ removal stages at various water treatment works in Scotland and have led to regular, controlled flushing of the distribution system being carried out to reduce Mn deposits in the pipes.

While catchment inputs from streams provide the primary, external loading of $\mathrm{Fe}$ and $\mathrm{Mn}$ to reservoirs and lakes, internal processes, both biochemical and physical, can be responsible for increased concentrations in the water column as a result of remobilisation and diagenetic (redox-controlled) release from the sediments. High concentrations of $\mathrm{Mn}$ in Loch Bradan (Gavin et al. 2001), for example, have been attributed to the dissolution of Mn-containing minerals at or near the sediment-water interface, and sediment core studies have shown that release of $\mathrm{Mn}$ from sediments is a common phenomenon in Scottish freshwater lochs (Bryant et al. 1997). Mobilisation of Fe and Mn during early diagenesis is coupled to suboxic conditions in the sediment where $\mathrm{Fe}(\mathrm{III})$ and $\mathrm{Mn}(\mathrm{IV})$, present in form of $\mathrm{Mn}$ and $\mathrm{Fe}$ (hydr)oxides, provide an electron acceptor for the microbial degradation of reactive organic matter (Froehlich et al. 1979; Lovley \& Phillips 1986). In the 


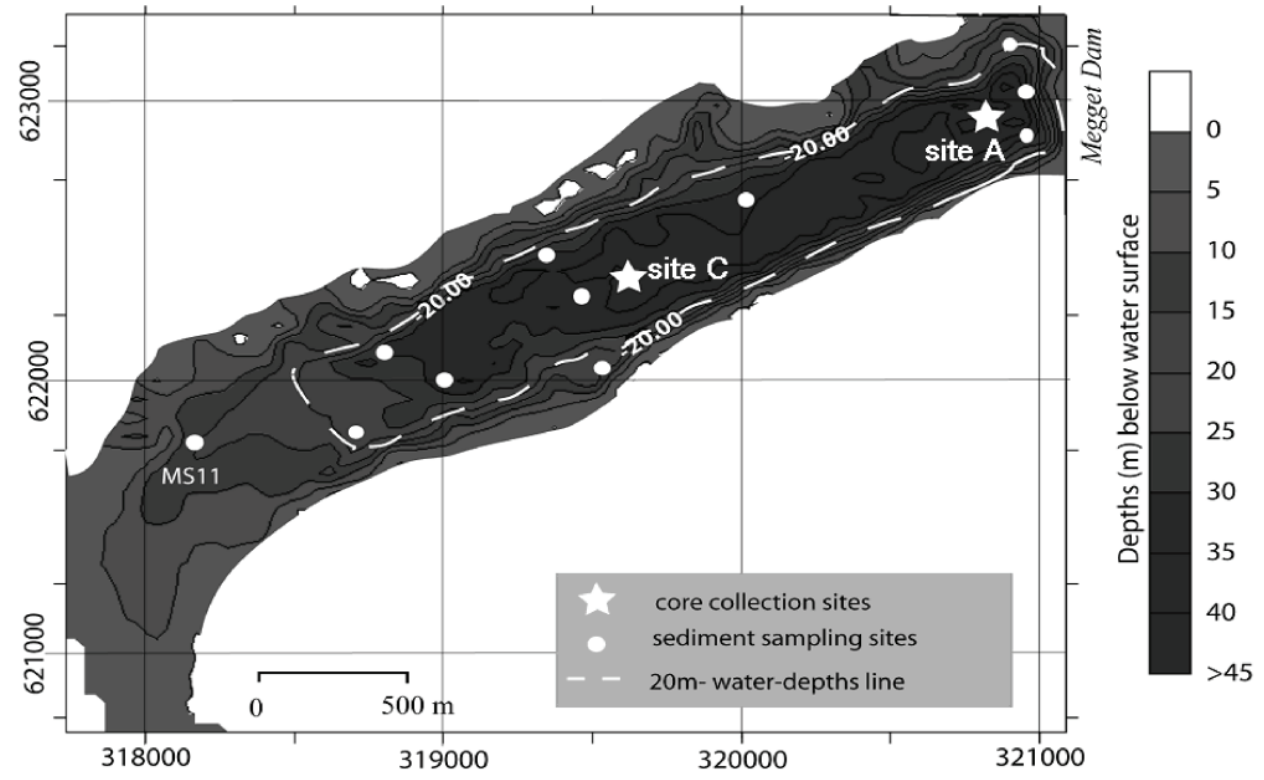

Fig. 1. Bathymetry of the Megget Reservoir including locations of core collection, sediment sampling and 20-m water depth line. (Bathymetric survey was carried out on 27 September 1999).

process, $\mathrm{Fe}(\mathrm{III})$ and $\mathrm{Mn}(\mathrm{IV})$ are reduced to the more soluble $\mathrm{Fe}(\mathrm{II})$ and $\mathrm{Mn}$ (II) and released into the porewaters from where they diffuse upwards towards the sediment-water interface. Where redox conditions are favourable, this can provide a constant input of dissolved species into the overlying water column (Davison et al. 1982; Warnken et al. 2001).

Advective transport, including sediment resuspension, resulting from wind/wave-induced turbulences has also been linked to increased metal (and nutrient) concentrations in the water column of aquatic systems (ten Hulscher et al. 1992; Brassard et al. 1994). Resuspension events can be generated by exposure of deep-water regions to higher energy regimes (e.g., wind or water movement) and often occur in reservoirs where large water level fluctuation and regular draw down events are frequent (Effler et al. 1998). Excessive reservoir draw down was held responsible for the increased metal release in the Dnieper reservoirs (Linnik \& Zubenko 2000).

In this study, laboratory-based experiments were carried out to investigate (1) how a reduced oxygen supply to the water column (as experienced during summer stratification) affects the sediment release of $\mathrm{Fe}$ and $\mathrm{Mn}$, and (2) what impact sediment resuspension (as experienced during autumn turnover/storm events), and related metal mobilisation from sediments, has on the water quality of the overlying water column. Undisturbed sediment cores were installed in the laboratory and subjected to various treatments simulating different internal and external forcing conditions (e.g., oxygen depletion and shear stress). This paper discusses the laboratory-based experiments and their implications for reservoir management.

\section{STUDY AREA}

The Megget Reservoir (Fig. 1) is located in the Southern Uplands in the UK, about $50 \mathrm{~km}$ south of Edinburgh (NGR 319 622). It is an important source of drinking water and one of Scottish Water's largest supply reservoirs. It has a surface area of $2.59 \mathrm{~km}^{2}$ and its yield to supply (at the time of construction in 1983) was estimated as $102.3 \mathrm{Ml} \mathrm{d}^{-1}$ (Jowitt \& Hay-Smith 2002).

The reservoir is a monomictic, oligotrophic system. Its catchment area is underlain by $\mathrm{Fe}$ and $\mathrm{Mn}$-rich Ordovician and Silurian greywackes and shales which are locally covered by glacial and post-glacial deposits (e.g., peat). The soils are predominated by organic-rich peaty podzols, peaty gleys and blanket peat and to a lesser degree by mineral soils including brown forest soils, rankers and podzols. The reservoir is fed by six major tributaries which, during periods of increased runoff, deliver high loads of organically-complexed $\mathrm{Fe}$ and $\mathrm{Mn}$ to the reservoir (Abesser et al. 2006). The deepest part of the reservoir is situated towards the east with a maximum depth of $55 \mathrm{~m}$ at the dam (at full capacity). The western part is relatively shallow with alluvial fans developed around areas of stream inflows. During periods of thermal stratification, bottom waters remain oxygenated but dissolved oxygen (DO) is depleted progressively from the lower layers of the reservoir (minimum DO $7.6 \mathrm{mg} \mathrm{L}^{-1}$ at $1 \mathrm{~m}$ above reservoir bottom). Distinct vertical gradients in total $\mathrm{Fe}$ and $\mathrm{Mn}$ concentrations develop during late summer/early autumn and differences between surface and bottom waters of up to $150 \mu \mathrm{g} \mathrm{L}^{-1}$ $(\mathrm{Fe})$ and $100 \mu \mathrm{g} \mathrm{L}^{-1}(\mathrm{Mn})$ have been observed prior to mixing and overturn of the reservoir (Abesser 2003). 
Tab. 1. Core properties and experimental treatment.

\begin{tabular}{lcccc}
\hline Core ID & $\mathrm{C} 1$ & $\mathrm{C} 3$ & $\mathrm{C} 5$ & $\mathrm{C} 6$ \\
\hline Core length & $13.5 \mathrm{~cm}$ & $20.0 \mathrm{~cm}$ & $11.5 \mathrm{~cm}$ & $18.0 \mathrm{~cm}$ \\
Treatment & Resuspension & $\begin{array}{c}\text { Diffusion } \\
\text { (top 4-5 cm) }\end{array}$ & $\begin{array}{c}\text { Resuspension } \\
\text { (top } 1-2 \mathrm{~cm})\end{array}$ & $\begin{array}{c}\text { Diffusion } \\
\left(21{ }^{\circ} \mathrm{C}\right)\end{array}$ \\
Duration of treatment & 21 days & 21 days & 21 days & 21 days \\
Sampling frequency & $3-4$ days & $3-4$ days & $3-4$ days & $3-4$ days \\
\hline
\end{tabular}

The reservoir sediments consist of grey-brown silty muds which dominate the central parts of the reservoir and are intermixed with fine sands closer to the shores. The organic carbon content (as determined by Loss on Ignition) of the surficial sediments (top $10-15 \mathrm{~cm}$ ) is relatively high and can make up a quarter $(24 \%)$ of the total dry mass (Abesser 2003). The sediment chemical composition varies between the shallow end of the reservoir and the deeper parts (in the middle and dam area) indicating variations in the proportions of feldspar, clay minerals, quartz and biogenic components in these sediments.

The Southern Uplands have a predominantly cool and temperate climate that is dominated by frontal systems from a general Atlantic source (mainly westerly direction). Wind speeds average around $3.9 \mathrm{~m} \mathrm{~s}^{-1}$ (median value calculated from hourly data between 01 September 1999 and 30 September 2001 measured at the Environmental Change Network site at Sourhope (NGR 387 622)) but strong winds from the north prevail during the winter and can exceed speeds of $20 \mathrm{~m} \mathrm{~s}^{-1}$.

\section{METHODS}

\subsection{Core collection}

Six undisturbed sediment cores were collected from the Megget Reservoir on $4^{\text {th }}$ October 2001 at two different sites (A and C) within the reservoir (see Fig. 1). At the time of core collection, the reservoir was well-mixed with no temperature or chemical stratification.

The sediment cores were collected with a Jenkins core sampler into $50 \mathrm{~cm}$-long perspex tubes with an inner diameter of $5 \mathrm{~cm}$. The sampler captures the upper $10-30 \mathrm{~cm}$ of the sediment and a corresponding column of overlying water without disturbing the core or the sediment interface (Mortimer 1971). Prior to core collection, 10 litres of reservoir water were collected in a sample-rinsed polyethylene container for use during the laboratory experiments.

On collection, the core quality was inspected and cores were arranged according to their future use. Two cores were used for (immediate) chemical sediment analysis and were prepared for dissection by removing the water overlying the sediment with a siphon. The final $5 \mathrm{~cm}$ of the water column (above the sediment) were collected into clean sample-rinsed polyethylene bottles for chemical analysis. The cores were then dissected into $1-\mathrm{cm}$ segments. The individual segments were transferred into pre-labelled plastic bags and stored in a cool box until they were transferred to the cold store. The cores collected for laboratory experiments remained sealed and were transported to the laboratory and stored in the cold store at $9{ }^{\circ} \mathrm{C}$ until the next day when they were required for the experimental setup. The time between collection of the cores and the first experimental sampling/measurements was $<3$ days.

\subsection{Experimental settings}

The four undisturbed sediment cores were installed in the laboratory and subjected to various treatments simulating different internal and external forcing conditions as summarised in table 1. Cores collected for the resuspension experiment, $\mathrm{C} 1$ and $\mathrm{C} 5$, were fitted with a wall-mounted motor to which a 20 -cm-long stainless steel stirrer with $1-\mathrm{cm}$ mixing blades was attached. The stirrer was adjusted to sit $12-14 \mathrm{~cm}$ above the sediment surface. The depth of resuspension was controlled by adjusting the speed of the stirrer and uniformity was achieved by constant revolutions. The cores were left uncovered and exposed to light in order to reproduce the conditions in the shallow areas of the reservoir which are exposed to wind-induced turbulence and prone to resuspension. Cores collected for the sediment diffusion study, C3 and C6, were wrapped in aluminium foil to reduce photosynthetic processes in the water column and then sealed with plastic film to minimise oxygen exchange at the water-air interface during core incubation. Core $\mathrm{C} 3$ was maintained at $9{ }^{\circ} \mathrm{C} \pm 1{ }^{\circ} \mathrm{C}$ in a temperature-controlled room to simulate conditions at the bottom of the reservoir during (thermal) stratification when the oxygen supply to the bottom layers is limited. In order to accelerate processes of oxygen consumption in the core water column, the second core (C6) was kept at a temperature of $21{ }^{\circ} \mathrm{C} \pm 2{ }^{\circ} \mathrm{C}$. The cores remained isolated from atmospheric oxygen throughout the incubation period, except for the short intervals of sample collection when the seal was removed for approximately 5 minutes.

The four cores were incubated over a 21-day period. At regular intervals (3-4 days), in situ measurements were made of temperature and redox potential. They were taken in the upper $10 \mathrm{~cm}$ of the water column in order to minimise column mixing and avoid disturbance of the sediment-water interface. The redox potential (Eh) was measured using a gel-filled Orion electrode (Thermo Scientific Inc.). All measurements were corrected to the $\mathrm{mV}$ values that would be obtained by a Standard Hydrogen Electrode (SHE) and converted to pE. Water column samples were collected for the analy- 
sis of total and dissolved metals as well as $\mathrm{pH}$ by slowly lowering a glass tube to a position just above the watersediment interface. The glass tube was then capped and an integrated sample of the water column was withdrawn. Samples collected for determining the water column $\mathrm{pH}$ were emptied into a clean glass beaker and the $\mathrm{pH}$ was measured immediately. All other samples were collected into clean polyethylene bottles. For the analysis of the dissolved (soluble-colloidal) metal fraction, samples were filtered through a $0.45 \mu \mathrm{m}$ pore size filter (Whatman) and acidified to $1 \%-\mathrm{vv}$ with concentrated AristaR $^{\odot}$ grade nitric acid. The core water column was then replenished with reservoir water that was collected on the day of core collection and stored at a temperature of $9{ }^{\circ} \mathrm{C} \pm 1{ }^{\circ} \mathrm{C}$. Prior to replenishing, the water temperature was adjusted to the core water temperatures of $9{ }^{\circ} \mathrm{C}$ and $21{ }^{\circ} \mathrm{C}$, respectively. After each measurement and sampling event (i.e. every 3-4 days), cores $\mathrm{C} 1$ and $\mathrm{C} 5$ were resuspended as follows: Core $\mathrm{C} 1$ was resuspended for 1 hour to a depth of $4-5 \mathrm{~cm}$ and core $\mathrm{C} 5$ was resuspended for 4 hours to a depth of $1-2 \mathrm{~cm}$. On completion of the experiments, the cores were dissected (as previously described 3.1 ) and the weakly-bound metal $(\mathrm{Fe}, \mathrm{Mn}, \mathrm{Al})$ fraction was determined as detailed below.

\subsection{Analytical methods}

\subsubsection{Sediment analysis}

A single extraction technique was applied to the sediment segments following the operationally-defined procedure by Loring and Rantala (1992) which is detailed in Abesser (2003). This method is based on the use of $25 \%-\mathrm{vv}$ acetic acid (HOAc) to release the proportion of weakly-bound metals from such sites as ionexchange positions, amorphous compounds of $\mathrm{Fe}$ and $\mathrm{Mn}$, carbonates and those metals weakly held in organic matter. Hence, the extracted fractions should approximate the proportion of reactive $\mathrm{Fe}$ and $\mathrm{Mn}$ that is available for diagenetic remobilisation, bearing in mind that some differences may exist between such chemical dissolution of metal oxides and the actual process of microbial utilisation of mineral-bound metals (Hyacinthe et al. 2006). By definition, the extracted fraction also includes freshly-formed $\mathrm{Fe}$ and $\mathrm{Mn}$ hydroxides that precipitated from the pore waters during core segmentation and drying. Consequently, changes in the extracted-metal profiles prior to and after the experiment also reflect changes in metal distribution in the pore waters during the incubation period.

For the (kinetic) extraction, $2 \mathrm{~g}$ of oven-dried and crushed (not grinded) sediment were extracted with 25 $\mathrm{ml}$ of $25 \%$-vv acetic acid (HOAc) by agitating the sample in an orbital shaker (at $200 \mathrm{rpm}$ ) for 6 hours. The supernatant was then decanted and the sediment was washed with $10 \mathrm{ml}$ deionised water to remove the remaining dissolved components. The supernatant as well as wash water were separated from the sediment by centrifugation and decanted into a 50-ml polyethylene container. The extracted sample was then made up to 50 $\mathrm{ml}$ with deionised water. All samples were stored at 4 ${ }^{\circ} \mathrm{C}$ in a temperature-controlled room until analysis by ICP-OES. Acidification of the samples was not necessary as the sample extract had an acidity of $10-12 \%-\mathrm{vv}$ HOAc and the $\mathrm{pH}$ was sufficiently low $(\mathrm{pH} \sim 2.5)$ to prevent re-adsorption of the metals to the walls of the storage vessels.

\subsubsection{Water sample and supernatant analysis}

Analysis of column water samples and sediment extraction (supernatant) samples was carried out using an Inductively Coupled Plasma-Optical Emission Spectrometer (ICP-OES). Water samples with metal concentrations significantly higher than the calibration range were diluted 20 -fold using $\operatorname{AristaR}^{\odot}$ grade nitric acid as dilutant. Sediment extraction samples were also diluted (1) 10-fold with de-ionised water to reduce the acidity of the sample to $1 \%$-vv (as required by the ICP OES analysis method); and (2) a further 10-fold with nitric acid to reduce metal concentrations to lie within the calibration range of the method.

\subsection{Calculating potential for wind-driven sediment resuspension}

In order to estimate how wind conditions at the Megget Reservoir might affect sediment resuspension, bottom shear stress values (fluid shear stress acting on the bottom sediment due to wind-induced wave action) and critical entrainment threshold values (critical shear stress value at which sediment of median particle size becomes entrained/resuspended) were calculated from the available wind speed, water depth and particle size data.

Particle size data were available from a sediment survey carried out in August 2000 (Abesser 2003) which included 11 sampling stations across the Megget Reservoir. Water depths at these sampling sites ranged from $9.3 \mathrm{~m}$ to $43.9 \mathrm{~m}$ (Fig. 1). The wind speed data were recorded at the ECN monitoring site at Sourhope (NGR 387 622) and the fetch for the western end of the reservoir was approximated as $1000 \mathrm{~m}$.

Calculations of bottom shear stress values were based on the method outlined in Lawson et al. (2007):

$$
\tau_{b_{\text {wаге }}}=\rho(f / 2)\left(U_{b}^{2}\right)
$$

where $\tau$ is bottom shear stress (Pa) due solely to waves, $U_{b}$ is the orbital velocity, $\rho$ is water density $\left(\mathrm{kg} \mathrm{m}^{-3}\right)$, and $\mathrm{f}$ is a friction factor based on wave amplitude and roughness length $k_{s}$ (which is assumed to be $3 \times D_{84}$ where $D_{84}$ is the grain diameter for which $84 \%$ of the sediment sample by mass is finer). Bottom wave orbital velocity and the friction factor were calculated following Lawson et al. (2007):

$$
U_{b}=\frac{H_{s i g} \pi}{T \sinh \left(\frac{2 \pi h}{\lambda}\right)}
$$


(a) $\mathrm{C1}$

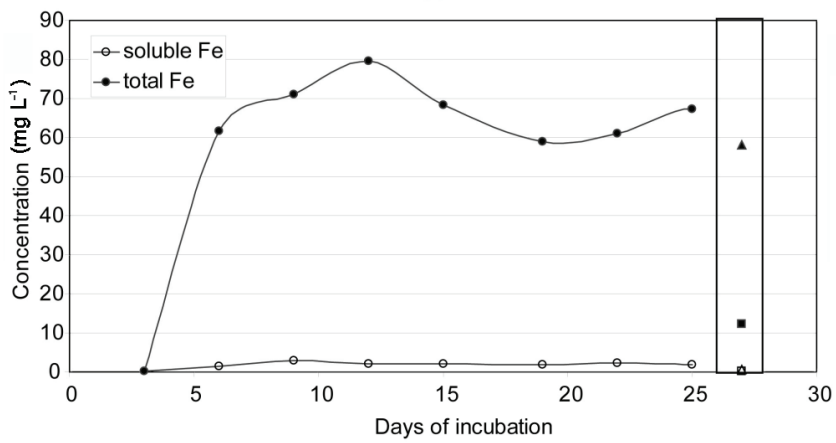

(b) $\mathrm{C5}$

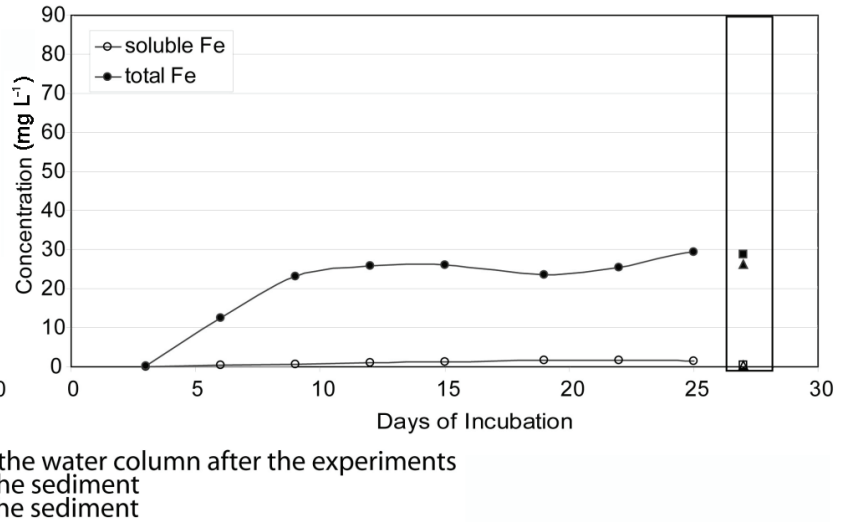

Fig. 2. Concentrations soluble-colloidal and total $\mathrm{Fe}$ in the water columns of $\mathrm{C} 1$ and $\mathrm{C} 5$ during the resuspension experiment.

(a) $\mathrm{C1}$

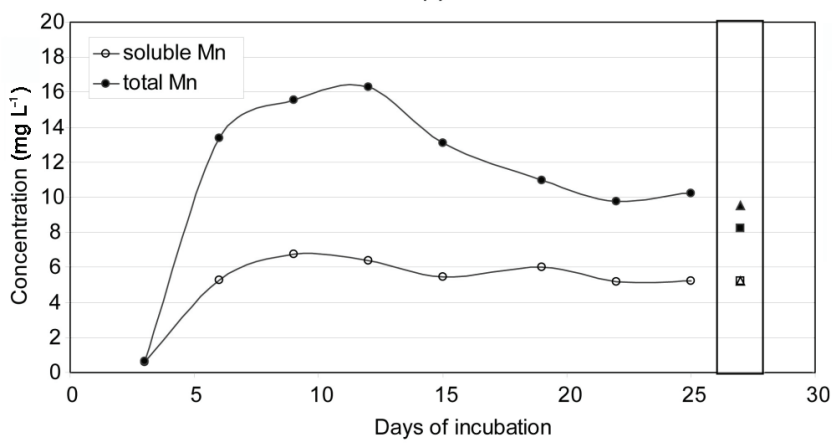

(b) $\mathrm{C5}$

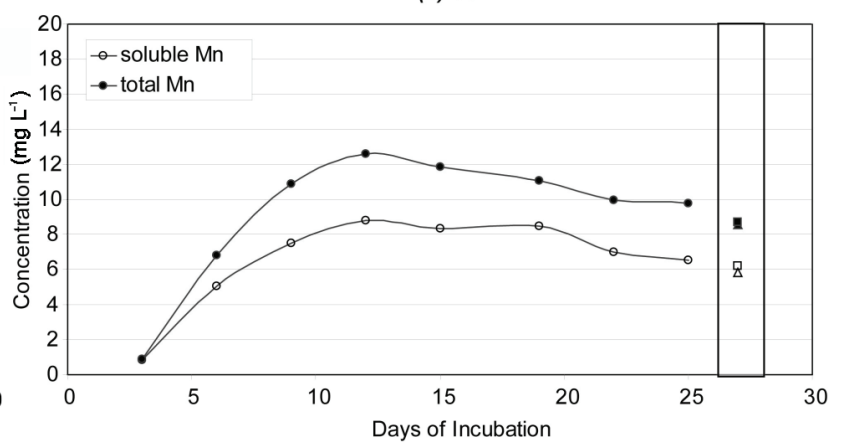

Concentrations in the water column after the experiments at $0-5 \mathrm{~cm}$ above the sediment at $>5 \mathrm{~cm}$ above the sediment

Fig. 3. Concentrations of soluble-colloidal and total $\mathrm{Mn}$ in the water columns of $\mathrm{C} 1$ and $\mathrm{C} 5$ during the resuspension experiment.

$$
f=0.4\left(A / k_{s}\right)^{-\frac{3}{4}} \text { for } 10<\mathrm{A} / \mathrm{ks}<100
$$

where $H_{\text {sig }}$ is the significant wave height $(\mathrm{m}), T$ is the wave period (s), $\lambda$ is the wavelength (m) and $A$ is wave amplitude (m).

Wave height $\left(H_{\text {sig }}\right)$ and wave periods $(T)$ were calculated using Airy Wave theory in the form presented by Prakash (2004):

$$
\begin{gathered}
H_{\text {sig }}=5.112 \times 10^{-4} w F^{1 / 2} \\
T=6.238 \times 10^{-2}(w F)^{1 / 3}
\end{gathered}
$$

where $w$ is the wind speed $\left(\mathrm{m} \mathrm{s}^{-1}\right), \mathrm{g}$ is the acceleration due to gravity $\left(\mathrm{m} \mathrm{s}^{-2}\right)$ and $\mathrm{F}$ is the maximum effective fetch $(\mathrm{m})$. The over-water wind speed $\mathrm{w}\left(\mathrm{m} \mathrm{s}^{-1}\right)$ was estimated to be $20 \%$ higher than the recorded over-land wind speed for fetches of less than $16 \mathrm{~km}$ (Prakash 2004). The shallow water wave equation was then used to calculate wavelength $\lambda(\mathrm{m})$ :

$$
\lambda=T \sqrt{g h}
$$

Critical entrainment of sediment with a grain-size less than fine sand can be calculated following Akahori et al. (2008):

$$
D_{*}=\frac{\left.\sqrt{\left(\frac{\rho_{s}}{\rho}\right.}-1\right) g D^{3}}{v}
$$

where $D *$ is the non-dimensional grain-size, $\rho_{s}$ and $\rho$ are sediment and water density, respectively, and $D$ is the median grain size $\left(D_{50}\right)$. The Shields curve, which is commonly used to estimate critical entrainment threshold values, is known to fit poorly to silts and clays and Cao et al. (2006) have proposed that a non-dimensional critical entrainment threshold $\tau$ can be formulated as:

$$
\tau_{*_{c}}=0.1414 D_{*}^{-0.2306}
$$

when $D *$ is $<6.61$, which is the case for the median grain sizes in the Megget Reservoir.

\section{RESULTS}

\subsection{Core Resuspension}

Iron and $\mathrm{Mn}$ concentrations in the water column of cores $\mathrm{C} 1$ and $\mathrm{C} 5$ increase dramatically during initial resuspension (Figs 2 and 3). They remain fairly constant during subsequent resuspension events and appear to be homogenously distributed throughout the core water 

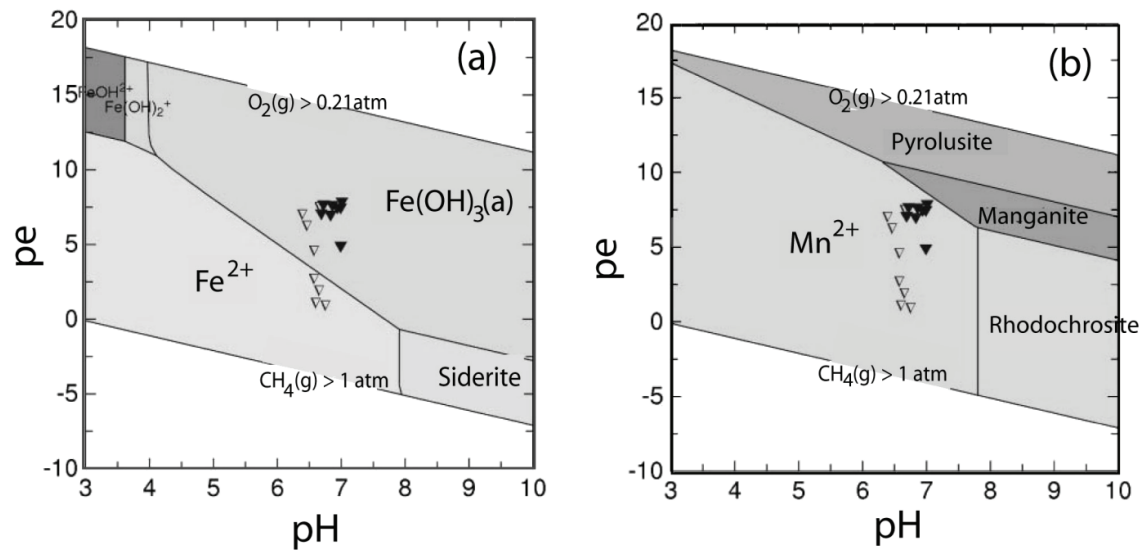

Fig. 4. pE-pH diagram for (a) Fe and (b) Mn species in (resuspension) cores $\mathrm{C} 1$ (open triangles) and $\mathrm{C} 5$ (closed triangles) (The diagram is drawn for conditions in the water column of core $\mathrm{C} 5$ at the end of the experiment: $\mathrm{Fe}=2.4 \times 10^{-2} \mathrm{~mol} \mathrm{~L}-1$ and $\mathrm{Mn}=$ $1.2 \times 10^{-1} \mathrm{~mol} \mathrm{~L}^{-1}$ at $19^{\circ} \mathrm{C}$.) Complexation with dissolved organic matter is not considered in the diagram.

column (Figs 2 and 3). Concentrations of total Fe (suspended plus dissolved) in the water column are up to 5 times higher than those of total $\mathrm{Mn}$ with maximum $\mathrm{Fe}$ concentrations of $79.5 \mathrm{mg} \mathrm{L}^{-1}$ in $\mathrm{C} 1$ and $29.4 \mathrm{mg} \mathrm{L}^{-1}$ in C5, compared to $16.3 \mathrm{mg} \mathrm{L}^{-1}$ and $12.6 \mathrm{mg} \mathrm{L}^{-1}$ of $\mathrm{Mn}$. Most $\mathrm{Fe}$ is present in particulate form and soluble-colloidal $\mathrm{Fe}$ only accounts for $3 \%$ to $4 \%\left(1.6-3.0 \mathrm{mg} \mathrm{L}^{-1}\right)$ in $\mathrm{C} 1$ and $4 \%$ to $7 \%\left(0.5-1.6 \mathrm{mg} \mathrm{L}^{-1}\right)$ in $\mathrm{C} 5$ of the total water column concentrations. The proportion of solublecolloidal $\mathrm{Mn}$ is much higher ranging between $39 \%$ and $55 \%$ (5.2-6.8 $\mathrm{mg} \mathrm{L}^{-1}$ ) in $\mathrm{C} 1$ and between $67 \%$ and $76 \%$ (5.1-8.8 $\left.\mathrm{mg} \mathrm{L}^{-1}\right)$ in $\mathrm{C} 5$. The total concentrations of $\mathrm{Fe}$ and $\mathrm{Mn}$ are higher in core $\mathrm{C} 1$, where a higher amount of sediment is suspended in the water column. The proportion of soluble-colloidal species, however, is lower even during reducing conditions where $\mathrm{Fe}^{2+}$ and $\mathrm{Mn}^{2+}$ are expected to predominate (Figs $4 \mathrm{a}$ and $4 \mathrm{~b}$ ).

The observed $\mathrm{Fe}$ and $\mathrm{Mn}$ concentrations in the resuspended core water columns are very high compared to concentrations in the reservoir due to the high sediment-to-water ratio (0.6-0.8) in these experimental cores. Assuming the dilution of these concentrations through homogenous mixing of the resuspended sediment into a $27 \mathrm{~m}$ water column (= water depths at deepest point during maximum reservoir draw down) the concentrations of total $\mathrm{Fe}$ and $\mathrm{Mn}$ reduce to $210 \mu \mathrm{g} \mathrm{\textrm {L } ^ { - 1 }}$ and $89 \mu \mathrm{g} \mathrm{L}^{-1}$ (if the top $2 \mathrm{~cm}$ of sediment are resuspended) and to $490 \mu \mathrm{g} \mathrm{L}^{-1}$ and $97 \mu \mathrm{g} \mathrm{L}^{-1}$ (if the top $5 \mathrm{~cm}$ of sediment are resuspended).

Water column redox $(\mathrm{pE})$ and $\mathrm{pH}$ of the resuspension cores are plotted in figure 4 . The plot shows that circumneutral $\mathrm{pH}$ prevails in the water column of both cores throughout the experiments with median $\mathrm{pH}$ of 6.57 and 6.86 in $\mathrm{C} 1$ and $\mathrm{C} 5$, respectively. Redox potentials remain high $(\mathrm{pE}>4)$ in core $\mathrm{C} 5$ throughout the experiment. In core $\mathrm{C} 1$, the $\mathrm{pE}$ drops dramatically after the initial resuspension event $(\mathrm{pE}<1)$ but then rises after 12 days of incubation until initial $\mathrm{pE}$ conditions are reestablished.
Core resuspension is associated with a significant increase in water colour, which changes from colourless to orange-brown during initial resuspension. The discolouration of the water persists throughout the duration of the experiments. Filtration of the samples using 0.45 $\mu \mathrm{m}$ Whatman filter disks removes colouration of the water completely together with more than $90 \%$ of the $\mathrm{Fe}$ and $24 \%$ to $60 \%$ of the $\mathrm{Mn}$.

\subsection{Core Diffusion}

In the diffusion cores, Fe concentrations (total + filterable) increase constantly during the course of the experiment (Fig. 5a). Concentrations increase from 0.8 to $4.1 \mathrm{mg} \mathrm{L}^{-1}$ in core $\mathrm{C} 6$ (maintained at $21{ }^{\circ} \mathrm{C} \pm 2{ }^{\circ} \mathrm{C}$ ) and from 0.5 to $2.0 \mathrm{mg} \mathrm{L}^{-1}$ in core $\mathrm{C} 3$ (maintained at 9 ${ }^{\circ} \mathrm{C} \pm 1{ }^{\circ} \mathrm{C}$ ). They are higher at the sediment-water interface $(0-5 \mathrm{~cm})$ (triangles in Figs 4 and 5) relative to the overlying water column $(>5 \mathrm{~cm}$ ) (rectangles in Figs 4 and 5). The overall increase in Fe during the incubation period is statistically significant (at the $95 \%$ confidence level) in both cores with slopes of $0.16\left(R^{2}=0.85\right)$ in core $\mathrm{C} 6$ and $0.05\left(R^{2}=0.68\right)$ in core $\mathrm{C} 3$. Most Fe is present in particulate form, although colloidal-soluble $\mathrm{Fe}$ accounts for $14 \%$ to $36 \%\left(0.27-1.37 \mathrm{mg} \mathrm{L}^{-1}\right)$ of the total concentration in core C6 and $13 \%$ to $43 \%(0.16-0.64$ $\mathrm{mg} \mathrm{L}^{-1}$ ) in core $\mathrm{C} 3$. Manganese is present almost exclusively (94-100\%) in colloidal-soluble form. Concentrations initially increase from $2.2 \mathrm{mg} \mathrm{L}^{-1}$ to $3.9 \mathrm{mg} \mathrm{L}^{-1}$ in core $\mathrm{C} 3$ (Fig. 6), but remain constant after 15 days. In core $\mathrm{C} 6, \mathrm{Mn}$ concentrations increase from $1.3 \mathrm{mg} \mathrm{L}^{-1}$ to $2.7 \mathrm{mg} \mathrm{L}^{-1}$ during the first 12 days of incubation but then decrease to $2.2 \mathrm{mg} \mathrm{L}^{-1}$ (Fig. 6). The increase is statistically significant (at the $95 \%$ confidence level) in core C3 (slope $=0.08, R^{2}=0.90$ ) but not in core C6.

As for the resuspension cores, the observed core water concentrations are very high compared to concentrations in the reservoir. However, accounting for dilution of these concentrations by diffusion into an overlying water column of 3-5 m yields concentrations 
(a) $\mathrm{C3}$

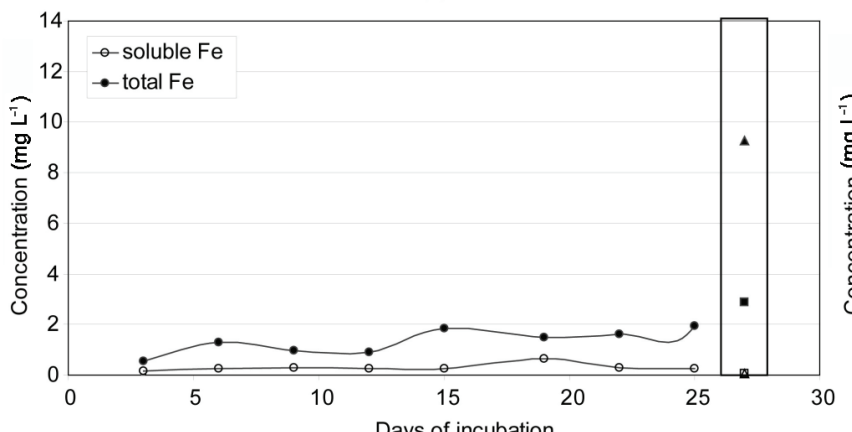

(b) $\mathrm{C6}$

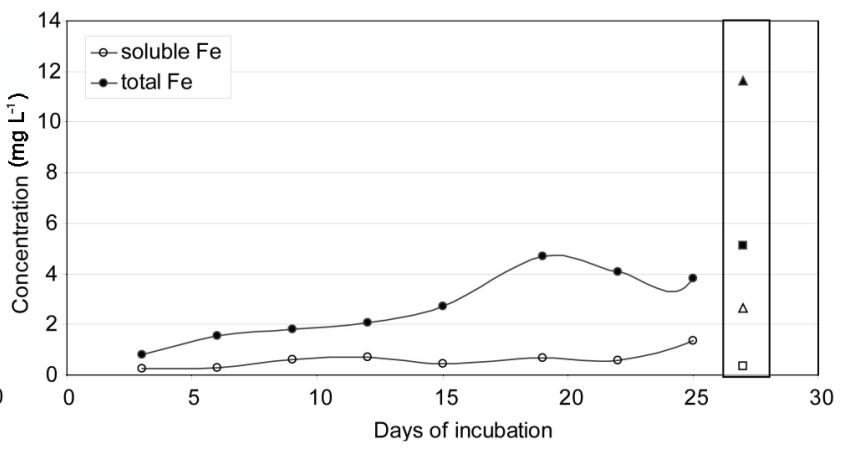

Concentrations in the water column after the experiments at $0-5 \mathrm{~cm}$ above the sediment
at $>5 \mathrm{~cm}$ above the sediment

Fig. 5. Concentrations of soluble-colloidal and total Fe in the water columns of C3 and C6 during the diffusion experiment.

(a) $C 3$

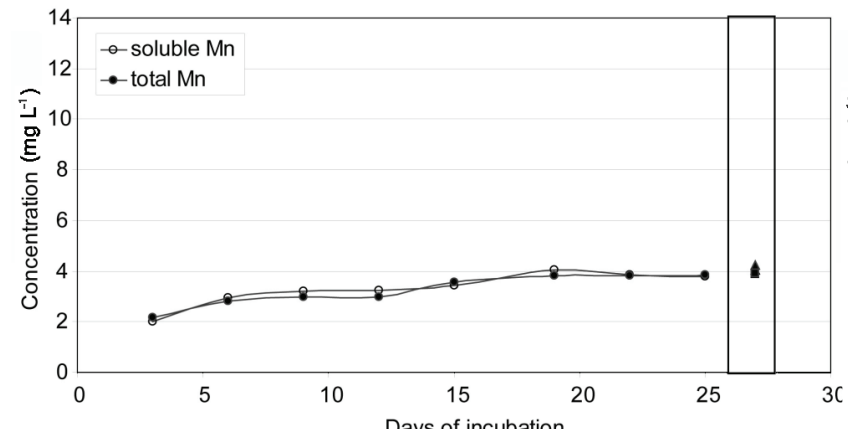

(b) $C 6$

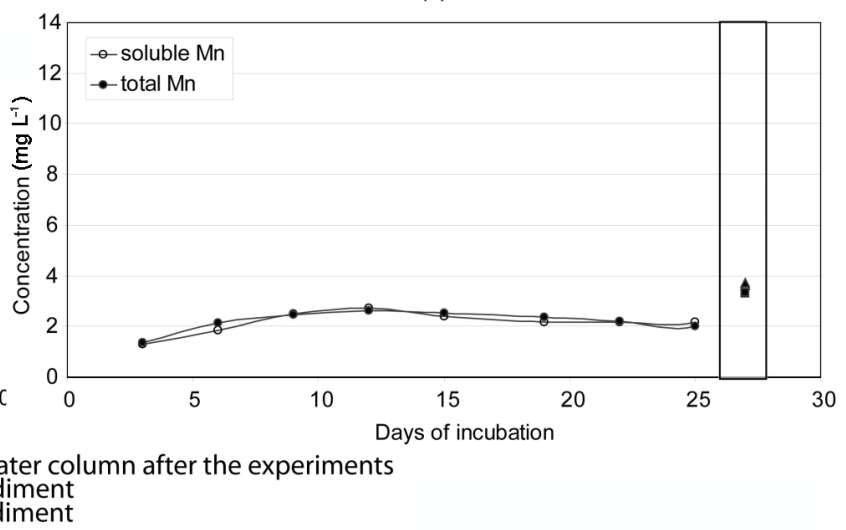

Fig. 6. Concentrations of soluble-colloidal and total $\mathrm{Mn}$ in the water columns of $\mathrm{C} 3$ and $\mathrm{C} 6$ during the diffusion experiment.

in the range of $100-160 \mu \mathrm{g} \mathrm{Fe} \mathrm{L}^{-1}$ and $70-110 \mu \mathrm{g} \mathrm{Mn} \mathrm{L^{-1 }}$ (at $21^{\circ} \mathrm{C}$ ) as well as $40-70 \mu \mathrm{g} \mathrm{Fe} \mathrm{L^{-1 }}$ and $80-130 \mu \mathrm{g} \mathrm{Mn}$ $\mathrm{L}^{-1}$ (at $\left.9{ }^{\circ} \mathrm{C}\right)$.

The $\mathrm{pH}$ and $\mathrm{pE}$ ranges measured in the core water column are plotted in figure 7 . The $\mathrm{pH}$ is similar in both cores $\left(\mathrm{pH}_{\text {median }}=6.70\right.$ and 6.54 , respectively) and shows little variation $(<0.25 \mathrm{pH}$ units) throughout the experiments. Redox potentials (pE) (measured in the upper water column) remain high throughout the experiment with $\mathrm{pE}_{\text {median }}=7.4$ in core $\mathrm{C} 3$ and $\mathrm{pE}_{\text {median }}=6$ in core $\mathrm{C} 6$.

\subsection{Core metal distribution}

Figure 8 illustrates the distribution of reactive $\mathrm{Fe}$ and $\mathrm{Mn}$ in the sediment cores analysed (a) prior to and $(b, c)$ after the experiments. Concentrations of aluminium (Al) are included in the graphs to provide a "conservative" reference for evaluating the relative changes in $\mathrm{Fe}$ and $\mathrm{Mn}$ in the cores. There are clear differences in the amount of $\mathrm{Fe}$ and $\mathrm{Mn}$ present within the sediment of the different cores. Concentrations are generally higher in the pre-experimental cores compared to the diffusion cores. The largest change is observed for extractable (reactive) Mn which declines from mean concentrations of $142 \mathrm{mg} \mathrm{L}^{-1}$ (A) and $144 \mathrm{mg} \mathrm{L}^{-1}(\mathrm{C} 4)$ in the pre-experimental cores to $19 \mathrm{mg} \mathrm{L}^{-1}$ (C3) and $15 \mathrm{mg} \mathrm{L}^{-1}$ (C6) in the diffusion cores. Comparison of means (based on Student's $t$-test) shows that this reduction is statistically significant (at the 95\% confidence level). Similarly, mean concentrations of extractable (reactive) $\mathrm{Fe}$ in the diffusion cores C3 $\left(184 \mathrm{mg} \mathrm{L}^{-1}\right)$ and C6 $\left(133 \mathrm{mg} \mathrm{L}^{-1}\right)$ differ significantly (at the $95 \%$ confidence level) from the pre-experimental core $\mathrm{C} 4\left(234 \mathrm{mg} \mathrm{L}^{-1}\right)$ but not from core $\mathrm{A}\left(134 \mathrm{mg} \mathrm{L}^{-1}\right)$. In the resuspended cores $\mathrm{C} 1$ and $\mathrm{C} 5$, concentrations are similar to pre-experimental conditions, only core $\mathrm{C} 1$ shows a (statistically) significant reduction in $\mathrm{Mn}$ (mean $65 \mathrm{mg} \mathrm{L}^{-1}$ ).

There are distinct differences in the vertical distribution of reactive $\mathrm{Fe}$ and $\mathrm{Mn}$ within the sediment cores. In the pre-experimental cores (Fig. 8a), Fe and Mn are enriched in the top $0-2 \mathrm{~cm}$ of the sediment. The Mn peak is better established than that of $\mathrm{Fe}$ and peaks at higher concentrations. Below $3 \mathrm{~cm}$, concentrations of extractable Fe constantly increase with depth with a maximum at around $7 \mathrm{~cm}$ in core $\mathrm{C} 4$. Sediment profiles of the diffusion cores (Fig. 8b) show similar enrichment of weakly-bound $\mathrm{Fe}$ in the upper $3-4 \mathrm{~cm}$ of the core, in 

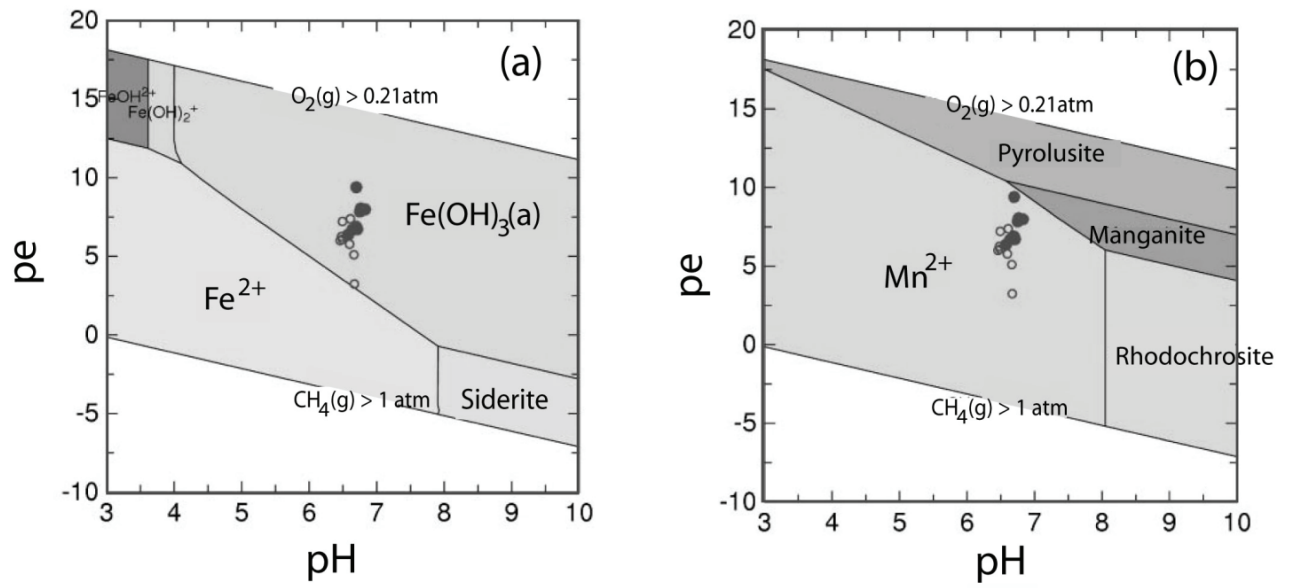

Fig. 7. pE-pH diagram for (a) Fe and (b) Mn species in (diffusion) cores $\mathrm{C} 3$ (closed circles) and C6 (open circles) (The diagram is drawn for conditions in the water column of core C6 at the end of the experiment: $\mathrm{Fe}=2.5 \times 10^{-2} \mathrm{~mol} \mathrm{~L}^{-1}$ and $\mathrm{Mn}^{2}=6.5 \times 10^{-5} \mathrm{~mol} \mathrm{~L}-1$ at $\left.19.4^{\circ} \mathrm{C}\right)$.

(a)

Pre-experiment

Core A Core C4

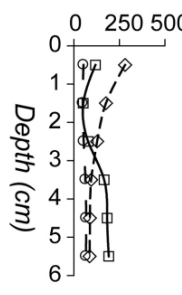

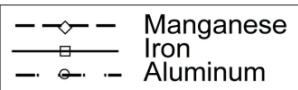

(b)

Diffusion

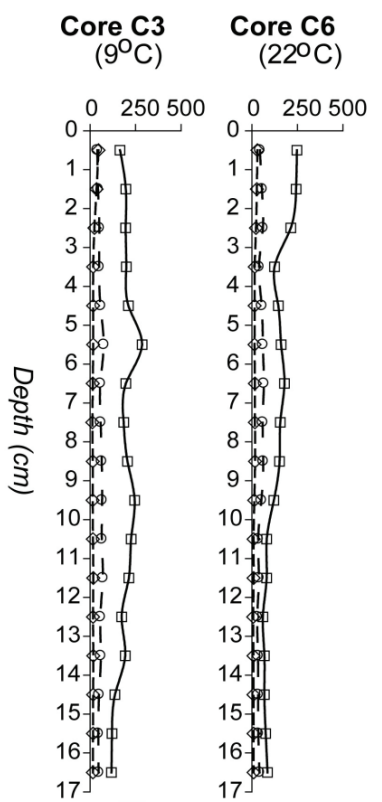

(c)

\section{Resuspension}

$\begin{array}{rr}\text { Core } \mathrm{C1} & \text { Core } \mathbf{C 5} \\ (4-5 \mathrm{~cm}) & (1-2 \mathrm{~cm})\end{array}$

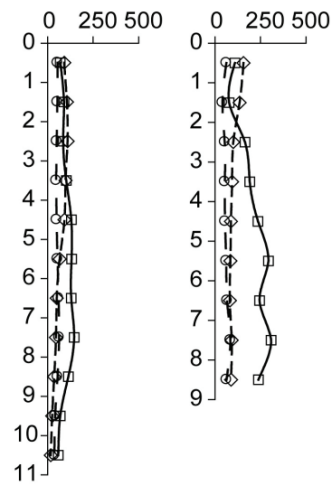

Fig. 8. Distribution of reactive $\mathrm{Mn}$ and $\mathrm{Fe}$ in the pre-experimental and experimental cores (plot shows concentrations in $\mathrm{mg} \mathrm{L}^{-1}$ (x-axis) versus depths below sediment-water interface in $\mathrm{cm}$ (y-axis)).

particular in C6. Below this zone, concentrations gradually decline and concentrations in the deeper parts of the sediment column are low. Core $\mathrm{C} 3$, incubated at $9{ }^{\circ} \mathrm{C}$, shows little Fe depletion at depth. However, the sediment of both cores is almost completely depleted of $\mathrm{Mn}$ with low concentrations $(\mathrm{Mn}<\mathrm{Al})$ at all depths throughout the profile. In the resuspension cores (Fig. $8 \mathrm{c}$ ), the distribution of reactive $\mathrm{Fe}$ and $\mathrm{Mn}$ is similar to that of the pre-experimental cores in core C5 (top 1-2 $\mathrm{cm}$ resuspended) but resembles that of the diffusion cores in core $\mathrm{C} 1$ (top $4-5 \mathrm{~cm}$ resuspended).

\subsection{Wind-driven sediment resuspension}

The grain-sizes available for transport have $D_{50}$ values that range from $7.95 \mu \mathrm{m}$ (MS11) to $15.03 \mu \mathrm{m}$ (MS6) (Tab. 2). Bottom shear stress estimates are calculated for the shallow part of the reservoir with water depths of $<20 \mathrm{~m}$ using equations 1-6. The results for site MS11 (water depths $13.8 \mathrm{~m}$ ) are presented in figure 9a for hourly wind speed data observed during the study period (September 1999-October 2001). The value of the critical entrainment threshold $\left(\tau_{*_{\mathrm{c}}}\right)$ at this site is 

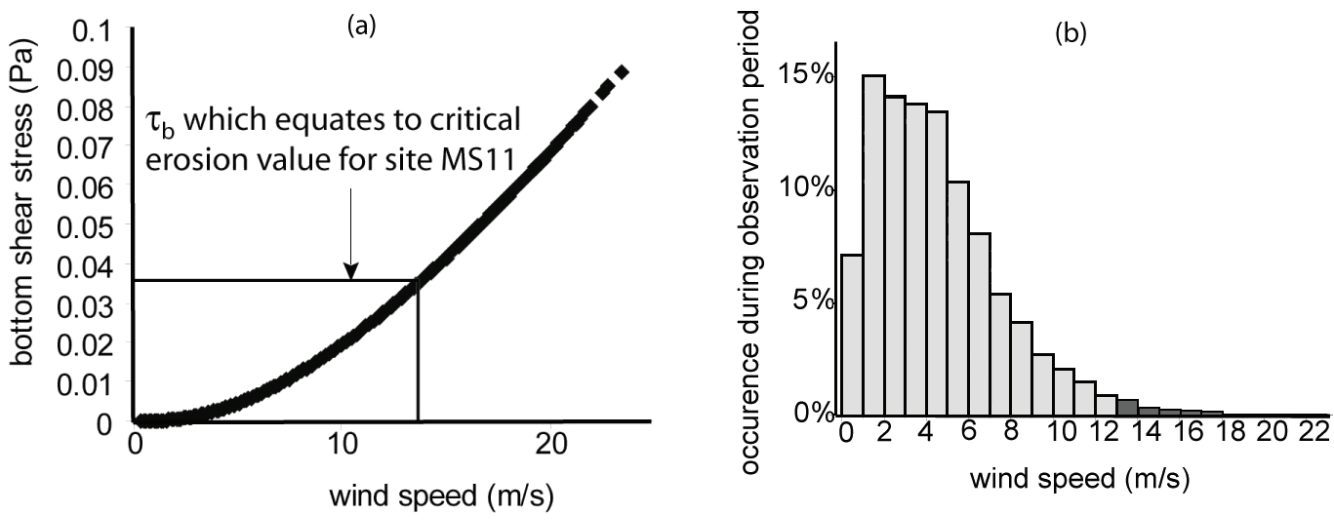

Fig. 9. (a) Bottom shear stress estimates at site MS11 and (b) wind-speed frequencies at the Megget Reservoir (Histogram summarises ECN hourly data for the period between September 1999 to October 2001. Darker columns represent occurrence of wind speeds $>13 \mathrm{~m} \mathrm{~s}^{-1}$ ).

equal to 0.27 (based on equations 7 and 8) and this value is exceeded for all bottom shear stresses greater than 0.035. Bottom shear stresses of this magnitude can be generated by wind speeds of $13 \mathrm{~m} \mathrm{~s}^{-1}$ and above.

Tab. 2. Water column depths and medium grain sizes $\left(D_{50}\right)$ at sediment sampling sites across the Megget Reservoir.

\begin{tabular}{ccc}
\hline Sample ID & Depth $(\mathrm{m})$ & $D_{50}(\mu \mathrm{m})$ \\
\hline MS1 & 20.4 & 8.75 \\
MS2 & 39.0 & 9.54 \\
MS3 & 43.9 & 12.96 \\
MS5 & 40.8 & 9.82 \\
MS6 & 29.6 & 15.03 \\
MS7 & 36.6 & 8.48 \\
MS8 & 19.2 & 8.74 \\
MS9 & 30.9 & 10.08 \\
MS11 & 13.8 & 7.95 \\
MS13 & 22.5 & 9.76 \\
MS14 & 33.2 & 11.02 \\
\hline
\end{tabular}

Such strong winds occur in the study region predominantly during the autumn and winter period. They are relatively infrequent (less than $2 \%$ of the time) (Fig. $9 \mathrm{~b}$ ), but have the potential to disturb sediments in the shallow areas of the reservoir with water depths below $20 \mathrm{~m}$. At full capacity, these areas make up about one third of the total reservoir area (Fig. 1).

\section{DISCUSSION}

Resuspension introduces high quantities of Fe and $\mathrm{Mn}$ into the core water columns. The five fold enrichment of (total) $\mathrm{Fe}$ relative to (total) $\mathrm{Mn}$ reflects the higher retention of $\mathrm{Fe}$ within the reservoir sediments (Abesser 2003). Almost all Fe in the resuspended water column is present in particulate form and $\mathrm{Fe}^{3+}$ appears to be the stable $\mathrm{Fe}$ species in the water column of the two cores during most of the experiment (Fig. 4a). Most $\mathrm{Fe}$ is probably present as non-reactive, refractory $\mathrm{Fe}$ oxides and/or incorporated in the crystal structure of clay minerals and silicates. Only one third is likely to be present as reactive oxyhydroxides (Tessier et al. 1979;
Davison \& De Vitre 1992), which can be reduced under low redox conditions and probably provide the main source of Fe within the sediments. Manganese is mostly present as dissolved $\mathrm{Mn}^{2+}$ which is the stable species at the prevailing $\mathrm{pH}-\mathrm{pE}$ conditions in the experimental columns (Fig. 4b). The high proportion of dissolved species reflects the low stability of particulate $\mathrm{Mn}$ in the aquatic environment where it is mostly present as reactive oxyhydroxides (Davison 1993). These are rapidly reduced in the suboxic water column and/or when encountering the sediment-water interface. As a result, Mn often accumulates near the sediment-water interface (Davison 1993) while the deeper sediment layers are depleted as seen in the profiles of the pre-experimental cores (Fig. 8). Extrapolating the observed core column concentrations to the conditions in the reservoir during the draw down period gives Fe concentrations in the range of $210-490 \mu \mathrm{g} \mathrm{L}^{-1}$. These values are comparable to concentrations measured in the reservoir (226-467 $\mu \mathrm{g}$ $\left.\mathrm{L}^{-1}\right)$ and at the treatment works $\left(350 \mu \mathrm{g} \mathrm{L}^{-1}\right)$ during maximum draw down, suggesting that resuspension was a major contributor to the observed water quality deterioration in the reservoir. The extrapolated concentrations of $\mathrm{Mn}$ are somewhat higher $\left(89-97 \mu \mathrm{g} \mathrm{L}^{-1}\right)$ than those measured at the treatment works $\left(50 \mu \mathrm{g} \mathrm{L}^{-1}\right)$. Since much of the $\mathrm{Mn}$ is present in dissolved form, it is likely that oxidation has removed some of the Mn from the water column during the $60 \mathrm{~km}$ passage of the water from the reservoir to the treatment works. Resuspension causes serious discolouration of the water which is probably caused by the presence of particulate matter (silt/clay particles, particulate organic matter, Fe particles) and not by dissolved organic substances which often are the cause for discolouration in upland streams and lakes (Freeman et al. 2001; Pace \& Cole 2002). These particles have low settling velocities and also provide good sorption sites for dissolved metals. The sorption potential of these particles can increase during resuspension as increased inter-particle collisions and enhanced particle disaggregation create additional, new sorption sites on newly-formed particle surfaces (Brass- 
ard et al. 1994). Sorption of Fe (and Mn) onto these new sites removes dissolved species from the water, as indicated in $\mathrm{C} 1$, but it also enhances the residence time of $\mathrm{Fe}$ (and $\mathrm{Mn}$ ) in the water column as the sorbed species are more stable under the prevailing $\mathrm{pH}-\mathrm{pE}$ conditions. Combined with low settling velocities, this implies that after resuspension events, prolonged time is required for the recovery of the system's original water quality.

Wind-induced resuspension in the Megget Reservoir is estimated to occur at wind speeds of $13 \mathrm{~m} \mathrm{~s}^{-1}$ and above and can affects sediments at water depth $<20 \mathrm{~m}$. At full capacity, these shallow areas constitute about one third of the total reservoir area (Fig. 1). Hence, water quality deteriorations resulting from such resuspension events may be substantial, particularly during autumn when the reservoir volume can be as low as $60 \%$ of the full reservoir capacity even in years of normal reservoir operation (i.e., no articifial draw down) (Abesser 2003). Wind speeds in excess of $13 \mathrm{~m} \mathrm{~s}^{-1}$ occur predominantly during the autumn and winter period and, under current climatic conditions, are relatively rare $(<2 \%)$. However, climate change scenarios predict a $5 \%$ change in wind speeds for Scotland as well as an increase in rainfall intensities during the winter month, particularly in eastern Scotland (Hulme et al. 2002; Barnett et al. 2006). This implies that natural, windinduced resuspension events may become more frequent and associated water quality problems (e.g., colouration) may prevail throughout the autumn/winter period until conditions are sufficiently calm to allow particle settling. Resuspension events can also be expected to occur in other supply reservoirs and/or freshwater lochs in the study region, most of which are located in similar geological and geomorphological settings. Besides the adverse effects on water quality, such events are likely to increase nutrient availability and entrainment in the water column, thereby impacting on the lake's ecosystem productivity (Schallenberg \& Burns 2004). The effect of increasing rainfall intensities on resuspension has not been investigated in this study. However, bottom currents generated by high discharges to the reservoir during intensive rainfall events can contribute to sediment resuspension and can even impact on deep lake/reservoir regions that are otherwise not affected by wind-induced stresses (Hawley \& Lee 1999). In addition to sediment disturbance, such high-rainfall events also supply large quantities of (total) $\mathrm{Fe}$ and $\mathrm{Mn}$ via inputs from the feeder streams with concentrations of up to $1200 \mu \mathrm{g} \mathrm{L}{ }^{-1}$ and $150 \mu \mathrm{g} \mathrm{L}^{-1}$, respectively, during peak runoff (Abesser et al. 2006).

Under undisturbed conditions, mobilisation within and release from the sediment becomes an important source of dissolved $\mathrm{Fe}$ and $\mathrm{Mn}$ in the water column. Concentrations of $\mathrm{Fe}$ and $\mathrm{Mn}$ are almost an order of magnitude lower, compared to those resulting from resuspension, and are mostly controlled by chemical factors (i.e., temperature, $\mathrm{pE}$, mineral solubility and saturation) rather than by physical processes. Sediment profiles suggest that $\mathrm{Fe}^{2+}$ and $\mathrm{Mn}^{2+}$ are mobilised within the sediment and released into the overlying water column. This release occurs even though oxic conditions prevail in the upper water column throughout the experiments (probably because oxygen enters the core water column during sample collection and core replenishment). However, soluble $\mathrm{Fe}^{2+}$ is not stable in the water column under these $\mathrm{pE}$ (and $\mathrm{pH}$ ) conditions (Fig. 7a) and is rapidly oxidised to particulate $\mathrm{Fe}^{3+}$ probably in the form of amorphous ferrihydroxides. Assuming a half life of 4 hours in oxygenated environments (pH 7, $10{ }^{\circ} \mathrm{C}$ ) (Davison \& Seed 1983), $\mathrm{Fe}^{2+}$ can be expected to travel about $0.5 \mathrm{~cm}$ (if only molecular diffusion operates) in a plentiful supply of oxidants before being re-oxidised (Hamilton-Taylor \& Davison 1995). This is consistent with observations in the core tubes where $\mathrm{Fe}$ precipitates form about $0.5-3 \mathrm{~cm}$ above the sediment on the inside of the core tubes. Dissolved $\mathrm{Mn}^{2+}$ is oxidised about 106 times slower than $\mathrm{Fe}^{2+}$ (at circumneutral pH) (Martin 2005) and is more stable in the core water columns of the diffusion cores (Fig. 7b). Its high mobility and the constant release of dissolved $\mathrm{Mn}^{2+}$ from the sediment has led to Mn depletion in the core sediments of $\mathrm{C} 3$ and C6 (Fig. 8) so that concentrations in the water column could no longer increase after 12-15 days (Fig. 3). Extrapolating from the concentrations in the diffusion cores to an overlying water column of 3-5 m gives concentrations similar to those measured in the reservoir $(\sim 3-5 \mathrm{~m}$ above the sediment) during summer stratification which averaged around $125 \mu \mathrm{g} \mathrm{L}{ }^{-1}$ for $\mathrm{Fe}$ and $105 \mu \mathrm{g} \mathrm{L}^{-1}$ for Mn. This confirms that sediment release, as simulated in this study, occurs during summer stratification. However, it is unlikely to cause water quality problems as the release of $\mathrm{Fe}$ is low (and $\mathrm{Fe}$ is also rapidly oxidised) and $\mathrm{Mn}$ within the reservoir sediments is probably depleted during summer stratification, thereby limiting the amount of Mn that can accumulate in the bottom waters. In addition, some of the Mn may actually be removed from the water column as indicated by the decline in Mn concentrations in core C6. A major pathway for such Mn removal in natural systems is bacterial Mn oxidation (Tebo et al. 1997) which results in the formation of biogenic Mn oxides in the form of vernadite (Wehrli et al. 1995), birnessite (Tebo et al. 2004) or reduced Mn oxides, such as hausmannite or manganite (Emerson 2000). These processes commonly occur at elevated temperatures, i.e., between $\sim 15^{\circ} \mathrm{C}$ to $\sim 30{ }^{\circ} \mathrm{C}$ (Tipping 1984) and could explain the formation of brown spots, interpreted as Mn precipitates, on the inside of core tube $\mathrm{C} 6$. The absence of such precipitates in the colder waters of core $\mathrm{C} 3\left(\sim 9^{\circ} \mathrm{C}\right)$ supports this assumption of biologically-mediated oxidation. The form in which the Mn oxide phase is present was not determined in this study, but should be investigated in future research efforts to establish the role of biota in Mn cycling within the reservoir. 
An obvious limitation of this study is the small number of cores and replicate treatments that were employed during the experiments. This means that there is only limited information on the spatial variability in metal concentrations and distribution within the reservoir sediments and implies that some of the observed differences in metal release may be due to heterogeneity in the sediment distribution and chemistry between the cores. Furthermore, the results from this incubation experiment only provide a "snapshot" of the fluxes between the sediment and the water. They are specific to the part of the reservoir where the cores were collected and the environmental conditions (temperature, $\mathrm{pH}$, redox, etc.) that prevailed in the core columns during incubation. Considering these limitations, sediment release rates were not calculated as part of this study as more spatially and temporally varied data are required to determine representative numbers.

\section{CONCLUSIONS}

Resuspension can introduce large quantities of Fe and $\mathrm{Mn}$ into the water column of the Megget Reservoir and, in this oligotrophic system, is far more effective than release from sediment diffusion. It is more important for the mobilisation of $\mathrm{Fe}$ which, in comparison to $\mathrm{Mn}$, is present in large quantities within the sediments. Under the current climate, natural resuspension events at the Megget Reservoir are rare, but are expected to become more frequent as climatic conditions change towards increased wind speeds and higher rainfall intensities. Such an increase is likely to affect other reservoirs and lochs in the study region leading to increased sediment resuspension with adverse effects on water quality and ecosystem productivity.

In the absence of physical disturbance, $\mathrm{Mn}$ and $\mathrm{Fe}$ are delivered to the water column by the rapid reduction of oxyhydroxide particles at the sediment water interface and/or within the sediment. Reductive dissolution and sediment release are unlikely to cause water quality problems in the Megget Reservoir as the release of $\mathrm{Fe}$ is low and $\mathrm{Mn}$ within the sediments will be quickly depleted. However, accumulation of these elements in the bottom waters may increase with changing climatic condition, in particular when the external $\mathrm{Mn}$ and $\mathrm{Fe}$ inputs increase as a result of higher catchment loading associated with the predicted rise in rainstorm intensities.

Although extrapolation of experimental results to in situ conditions is often difficult and despite the limited number of cores, this laboratory study has successfully separated the internal processes related to resuspension and sediment diffusion and has helped to evaluate their potential impact on the water quality of the Megget Reservoir in the past and in the future.

\section{ACKNOWLEDGEMENTS}

The authors would like to thank Alexander Kirika (CEH Bush) for his help with collecting the sediment cores, Margaret and Colin Neal (CEH Wallingford) for providing access to and help with the ICP-OES analysis as well as for their continued support during the project and their great hospitality. Further thanks to Richard Bates (University of St Andrews) for providing the bathymetric data of the Megget Reservoir as well as to Heather Wickham (CEH Wallingford) for her help with running the ICP-OES. David Kinniburgh (BGS Wallingford) is thanked for the provision of the PhreePlot programme which was used for calculating and plotting $\mathrm{pH}-\mathrm{pE}$ diagrams as well as for his invaluable comments on this manuscript. We further thank the two anonymous reviewers for their comments which greatly helped to improve this manuscript. The Environmental Change Network (ECN) is acknowledged for providing all wind speed data used in this study. Funding and facilities for this study have been provided by East of Scotland Water (now part of Scottish Water) and by the University of St Andrews.

\section{REFERENCES}

Abesser, C. 2003. Water quality functioning of an upland reservoir and its catchment area-with particular emphasis on iron and manganese. $\mathrm{PhD}$ thesis. University of St Andrews.

Abesser, C., R. Robinson \& C. Soulsby. 2006. Iron and manganese cycling in the storm runoff of a Scottish upland catchment. J. Hydrol., 326: 59-78.

Akahori, R., M. Schmeeckle, D. Topping \& T. Melis. 2008. Erosion properties of cohesive sediments in the Colorado River in Grand Canyon. River Res. Appl., 24: 1160-1174.

AWWA, American Water Works Association. 1987. Research needs for the treatment of iron and manganese. Report of the AWWA Trace Inorganic Substances Committee. J. Am. Water Works Assoc., 79: 119-122.

Barnett, C., J. Hossell, M. Perry, C. Procter \& C. Hughes. 2006. Patterns of climate change across Scotland. Technical Report. SNIFFER Project CC03, Scotland \& Northern Ireland Forum for Environmental Research.

Brassard, P., R.J. Kramer, A. Mcandrews \& E. Mueller. 1994. Metal-sediment interaction during resuspension. Hydrobiologia, 284: 101-112.

Bryant, C.L., J.G. Farmer, A.B. Mackenzie, A.E. Bailey-Watt, \& A. Kirika. 1997. Manganese behaviour in sediments of diverse Scottish freshwater lochs. Limnol. Oceanogr., 42: 918-929.

Cao, Z., G. Pender \& J. Meng. 2006. Explicit formulation of the Shields Diagram for incipient motion of sediment. Journal of Hydraulic Engineering, ASCE Publications 132: 1097-1099.

Davison, W. 1993. Iron and manganese in lakes. Earth-Sci. Rev., 34: 119-163.

Davison, W., \& R.R. De Vitre. 1992. Iron particles in freshwater. In: J. Buffle \& H. P. Van Leuwen (Eds), Environmental particles. Lewis: 315-355.

Davison, W. \& G. Seed. 1983. The kinetics of the oxidation of ferrous iron in synthetic and natural waters. Geochim. Cosmochim. Acta, 47: 67-79.

Davison, W., C. Woof \& E. Rigg. 1982. The dynamics of iron and manganese in a seasonally anoxic lake; direct measurement of fluxes using sediment traps. Limnol. Oceanogr., 27: 987-1003.

DWI. Drinking Water Inspectorate. 2000. The Water Supply (Water Quality) (England and Wales) Regulations 2000. SI No.3184. 
Effler, S.W., R.K. Gelda, D.L. Johnson \& E.M. Owens. 1998. Sediment resuspension in the Cannonsville Reservoir. Lake Reserv. Manage., 14: 225-237.

Emerson, D. 2000. Microbial oxidation of Fe(II) and Mn(II) at circumneutral pH. In: D.R. Lovley (Ed.), Environmental Microbe-Metal Interactions. ASM Press: 31-52.

Froehlich, P.N., G.P. Klinkhammer \& M.L. Bender. 1979. Early oxidation of organic matter in pelagic sediments of the eastern equatorial Atlantic: suboxic diagenesis. Geochim. Cosmochim. Acta, 43: 1075-1090.

Gavin, K.G., J.G. Farmer, M.C. Graham, A. Kirika \& A. Britton. 2001. Manganese-humic interactions in the catchment, water and sediment of Loch Bradan, S.W. Scotland. In: R.S. Swift \& K.M. Spark (Eds), Understanding and managing Organic Matter in Soils, Sediments and Waters. IHSS.

Hamilton-Taylor, J., \& W. Davison. 1995. Redox-driven cycling of trace elements in lakes. In: A. Lerman, D.M. Imboden \& J.R. Gat (Eds), Physics and Chemistry of Lakes. Springer-Verlag, Berlin: 217-263.

Hawley, N. \& C.-H. Lee. 1999. Sediment resuspension and transport in Lake Michigan during the unstratified period. Sedimentology, 46: 791-805.

Heal, K.V. 2001. Manganese and land-use in upland catchments in Scotland. Sci. Total Environ., 265: 169-179.

Hsiung, T. \& T. Tisue. 1994. Manganese dynamics in Lake Richards B. Russell. In: L.A. Baker (Ed.), Environmental Chemistry of Lakes and Reservoirs. Advances in Chemistry Series. Amercan Chemical Society, Washington DC: 499-524.

Hulme, M., G.J. Jenkins, X. Lu, J.R. Turnpenny, T.D. Mitchell, R.G. Jones, J. Lowe, J.M. Murphy, D. Hassell, P. Boorman, R. McDonald \& S. Hill. 2002. Climate Change Scenarios for the United Kingdom: The UKCIP02 Scientific Report. Tyndall Centre for Climate Change Research, School of Environmental Sciences, University of East Anglia.

Hyacinthe, C., S. Bonneville \& P. Van Cappellen. 2006. Reactive iron(III) in sediments: Chemical versus microbial extractions. Geochim. Cosmochim. Acta, 70: 4166-4180.

Jowitt, P.W. \& D. Hay-Smith. 2002. Reservoir yield assessment in a changing Scottish environment. Sci. Total Environ., 294: 185-199.

Lawson, S., P. Wiberg, K. Mcglathery \& D. Fugate. 2007. Wind-driven sediment suspension controls light availability in a shallow coastal lagoon. Estuaries and Coasts, 30: 102-112.

Linnik, P.M. \& I.B. Zubenko. 2000. Role of bottom sediments in the secondary Pollution of aquatic environments by heavy metal compounds. Lakes Reserv. Res. Manage., 5: 11-21.

Little, D.I. \& C.J. McFadzean. 1991. Bradan water treatment works extensions and upgrading. In: M.D.F. Haigh \& C.P. James (Eds), Water and environmental management. Ellis Horwood: 178-188.

Livens, F.R. 1991. Chemical reactions of metals with humic material. Environ. Pollution, 70: 183-208.

Received: March 2009

Accepted: September 2009
Loring, D.H. \& R.T.T. Rantala. 1992. Manual for the geochemical analyses of marine sediments and suspended particulate matter. Earth-Sci. Rev., 32: 235-283.

Lovley, D.R. \& E.J.P. Phillips. 1986. Organic Matter Mineralization with Reduction of Ferric Iron in Anaerobic Sediments. Appl. Environ. Microbiol., 51: 683-689.

Martin, S.T. 2005. Precipitation and Dissolution of Iron and Manganese Oxides. In: V.H. Grassian (Ed.), Environmental Catalysis. CRC Press: 61-82.

Mcauliffe, T.F., R.J. Lukatelich, A.J. Mccomb \& S. Qiu. 1998. Nitrate applications to control phosphorous release from sediments of a shallow eutrophic estuary: An experimental approach. Mar. Freshw. Res., 49: 463-475.

Mortimer, C.H. 1971. Chemical exchanges between sediments and water in the Great Lakes - Speculations on probable regulatory mechanism. Limnol. Oceanogr., 16: 387-404.

Pace, M.L. \& J.J. Cole. 2002. Synchronous variation of dissolved organic carbon and color in lakes. Limnol. Oceanogr., 47: 333-342.

Prakash, A. 2004. Water Resources Engineering: Handbook of Essential Methods and Design. ASCE Publications.

Schallenberg, M. \& C.W. Burns. 2004. Effects of sediment resuspension on phytoplankton production: teasing apart the influences of light, nutrients and algal entrainment. Freshwat. Biol., 49(2): 143-159.

Schofield, T., R. Perkins \& J.S. Simms. 1991. Frankley watertreatment works development:pilot studies. JIWEM, 5: 370-380.

Tebo, B.M., J.R. Bargar, B.G. Clement, G.J. Dick, K.J. Murray, D. Parker, R. Verity \& S.M. Webb. 2004. Biogenic Manganese oxides: Properties and mechanisms of formation. Annu. Rev. Earth. Pl. Sc., 32: 287-328.

Tebo, B.M., W.C. Ghiorse, L.G. Van Waasbergen, P.L. Siering \& R. Caspi. 1997. Bacterially mediated mineral formation; insights into manganese(II) oxidation from molecular genetic and biochemical studies. Rev. Mineral. Geochem., 35: 225-266.

ten Hulscher, T.E.M., G.A.J. Mol \& F. Lüers. 1992. Release of metals from polluted sediments in a shallow lake: quantifying re-suspension. Hydrobiologia, 235/236: 97-105.

Tessier, A., P.G.C. Campbell \& M. Bisson. 1979. Sequential Extraction Procedure for the Speciation of Particulate Trace Metals. Anal. Chem., 51: 844-851.

Tipping, E. 1984. Temperature dependence of Mn(II) oxidation in lakewaters: a test of biological involvement. Geochim. Cosmochim. Acta, 48: 1353-1356.

Warnken, K.W., G.A. Gill, L.L. Griffin \& P. H. Santschi. 2001. Sediment-water exchange of $\mathrm{Mn}, \mathrm{Fe}, \mathrm{Ni}$ and $\mathrm{Zn}$ in Galveston Bay, Texas. Mar. Chem., 73: 215-231.

Wehrli, B., G. Friedl \& A. Manceau. 1995. Reaction Rates and products of manganese oxidation at the sediment-water interface. In: C.P. Huang, C.R. O'Melia \& J.J. Morgan (Eds), Aquatic Chemistry, Interfacial and Interspecies Processes. ACS Advances in Chemistry Series: 111-138.

Zaw, M. \& B. Chiswell. 1999. Iron and manganese dynamics in lake water. Water Res., 33(8): 1900-1910. 